\title{
CORELATION OF MULTIPLE INTELLIGENCE PROFILES ON INITIAL CONDITIONS OF PLANT ANATOMY PRACTICUM TO THE NEEDS OF A BLENDED LEARNING DIGITAL MICROSCOPE
}

\author{
Sugianto Sugianto $^{1 *}$, Ani Fitriani ${ }^{2}$, Sri Anggraeni', Wawan Setiawan ${ }^{2}$ \\ ${ }^{1}$ Program Studi Pendidikan Biologi, Universitas Wiralodra, Jl. Ir. H. Juanda KM.03, \\ Indramayu 45213, Indonesia \\ ${ }^{2}$ Program Studi Pendidikan IPA, Sekolah Pascasarjana Universitas Pendidikan Indonesia, \\ J1. Dr. Setiabudi No. 229, Bandung 40154, Indonesia \\ ${ }^{*}$ Email: sugianto@unwir.ac.id ${ }^{\text {a) }}$
}

Doi: https://doi.org/10.31943/mangiferaeduv4i2.82

Received: 10 Desember 2019 Accepted: 27 Januari 2020 Published: 31 Januari

Citasi: Sugianto., Fitriani, A., Anggraeni, S., \& Setiawan, W. 2020. Corelation of Multiple Intelligence Profile on Initial Conditions of Plant Anatomy Practicum to The End of A Blended Learning Digital Microscope. Jurnal Mangifera Edu, 4(2), 84-93.

\section{ABSTRACT}

The practice of plant anatomy using a light microscope indicates the immeasurable diversity of students' intelligence in making observations, such as logical-mathematical intelligence, visual-spatial intelligence, bodily-kinesthetic intelligence, and naturalistic intelligence. The population of this study were 35 prospective biology education teacher candidates, a sample selected using Purposiv Sampling, citing the limited number of samples. This study uses a questionnaire response instrument to determine the response of multiple intelligence profile of the initial conditions of plant anatomy practicum and blended learning digital microscope needs profile. All instruments are in the valid and reliable categories. Data analysis of the relationship between multiple intelligence profiles on the initial conditions of plant anatomy practicum to the needs of a blended learningbased digital microscope was analyzed quantitatively by Pearson's bivariate correlation test. Compound intelligence profile at the initial conditions of plant anatomy practicum has a low criterion, the profile of students' needs for blended learning digital microscope has high criteria, and there is a significant relationship between the profile of compound intelligence at the initial condition of plant anatomy practicum towards the needs of a blended learning-based digital microscope.

Keywords: Multiple Intelligence, Digital Microscope, Blended Learning

\section{INTRODUCTION}

The results of the preliminary study can be seen that the practicum of plant anatomy using a light microscope indicates the weakness of students' multiple intelligence in making observations, such as logical-mathematical intelligence, visual-spatial intelligence, physical-kinesthetic intelligence, and naturalistic intelligence. In physical-kinesthetic 
intelligence, students are often not careful in regulating revolvers and magnifying the objective lens of a light microscope. In logical-mathematical intelligence, students cannot analyze and measure carefully observed plant cells. In visual-spatial intelligence, students are less careful in seeing observations of shape, color and space between cells in plant tissue.

Based on these problems, the researchers conducted a survey of the initial conditions of the plant anatomy practicum and a survey of the need for a digital microscope based on blended learning. The results of various digital microscopy studies show that, virtual microscope systems increase learning productivity, learning efficiency, critical thinking, ease of communication and student confidence (Tian et al., 2014), because virtual microscope slides are easy to navigate, and virtual image quality is better from a normal microscope (Hamilton, Wang, \& McCullough, 2012). The interactive application of a smartphone microscope can facilitate exploratory stimulation of microscopic observations of organisms, this smartphone microscope interactive design combines elements of learning microorganisms and games (Kim et al., 2016). The use of Atomic Force Microscopy (AFM) in biology classes can improve compound intelligence as follows: 1) students can directly observe nanoscale nanoscale nanostructures, 2) students have the opportunity of science to prove how nanoscale micro-structures work in biological samples related to engineering - application of engineering - as well as learning applications of various nano micro-structures, 3) The formation of student experiences in the learning process that can be beneficial in learning science (Sunlee et al, 2013). Epifluorescence microscopy can motivate learning and carry out scientific investigations of students (Stewart \& Giannini, 2016), because epifluorescence microscopy has several advantages such as selective aircraft illumination microscopy (SPIM) which lasts several hours to several days (Kaufmann, Mickoleit, Weber, \& Huisken, 2012), consisting of two detection lenses and lighting objectives, which allows rapid toto fluoresence imaging of biological specimens with subcellular resolution (Krzic, Gunther, Saunders, Streichan, \& Hufnagel, 2012), and has a flexible automatic form design with the ability to facilitate transitions and others (Barber et al., 2013).

In this study several research questions are described as follows: 1) how is the profile of compound intelligence in the initial conditions of plant anatomy practicum, 2) how is the profile of student needs for digital microscope based on blended learning, and 3) how is the relationship of compound intelligence profile in the initial condition of plant anatomy practicum of the need for a blended learning-based digital microscope? 


\section{RESEARCH METHODS}

The population of this study was 35 prospective biology education teacher candidates, with a sample selected using purposive sampling, citing the limited number of samples. This study uses a questionnaire response instrument to determine the response of multiple intelligence profile of the initial conditions of plant anatomy practicum and blended learning digital microscope needs profile. All instruments are in the valid and reliable categories.

Research Procedure, in stage 1 is a preliminary study conducted by researchers with the intention of looking for references in determining the problem to be able to identify it. Thus researchers can easily get a picture of the problem identification of the title to be studied. Phase 2, researchers prepare all research tools. Phase 3, the research instrument was used in the experimental class. Phase 4, the data obtained in the field were then analyzed to find out the profile of multiple intelligences in the initial conditions of plant anatomy practicum, the profile of students' needs for a digital microscope based on blended learning, and to determine the relationship of the profile of compound intelligence in the initial conditions of plant anatomy practicum to the needs of a digital microscope based on blended learning. Stage 5, after the data is analyzed, the research results are obtained. Data analysis of the relationship between multiple intelligence profiles on the initial conditions of plant anatomy practicum to the needs of a blended learning-based digital microscope was analyzed quantitatively by Pearson's bivariate correlation test.

\section{RESULTS AND DISCUSSION}

\section{Preliminary Survey Results for Learning Plant Anatomy Practicum}

The instrument that was used to survey the initial conditions of learning the practice of plant anatomy was a questionnaire instrument given to the fourth grade kaka who had attended a plant anatomy practicum with a total of 35 respondents from IAIN Sheikh Nurjati's Biology Education Study Program. The recapitulation of the response to the initial conditions of learning the practice of plant anatomy can be seen in Figure 1. 


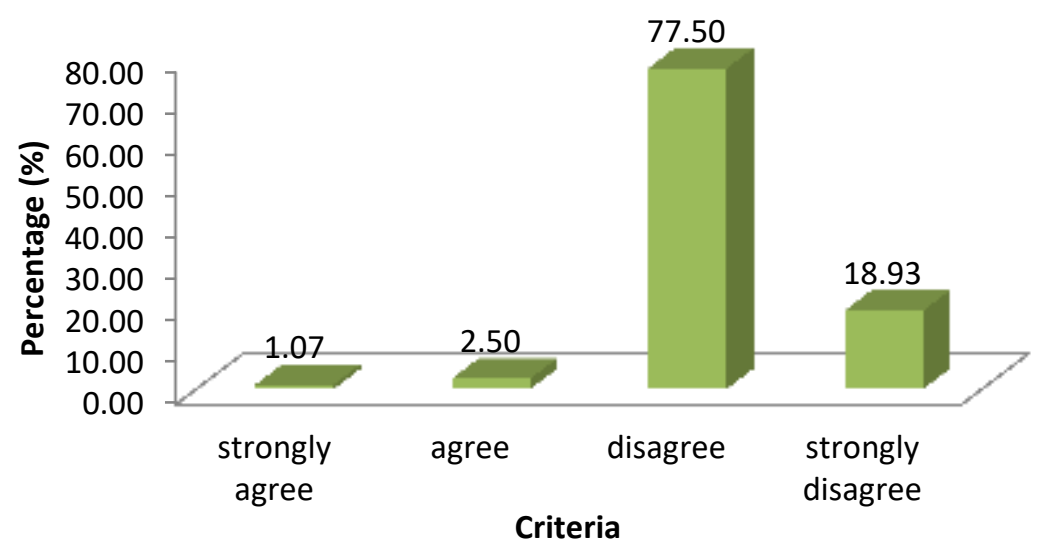

\section{Figur. 1. Recapitulation of Analysis of Student Response Data on the Initial Conditions of Plant Anatomy Practicum learning}

Based on Figure 1. shows that the results of the analysis of student response data analysis recapitulation to the initial conditions of plant anatomy practicum learning, namely a small proportion of students respond very much in response to agree with positive responses, most students respond to disagree and not strongly agree with negative responses. Then it can be seen the results of the analysis addressed the percentage of survey results that is $23.43 \%$ with a low category.

Based on the results of the survey it can be concluded that the initial conditions of learning in plant anatomy practicum indicate that there is no facilitation of compound intelligence for students. This is evident that students do not feel trained in operating the microscope and determine the magnification of the microscope, which means that the kinesthetic physical intelligence of students has not been facilitated. Students feel not facilitated in counting the number of cells, analyzing cells and measuring various cell shapes, which means the mathematical logical intelligence of students has not been facilitated. Students find it difficult when visualizing and identifying the results of cell observations, which means students' spatial visual intelligence has not been facilitated. Students feel they have not been facilitated in exploring the ability to recognize various cell organelles and tissues, which means that the naturalist intelligence of students has not been facilitated. Based on these problems, a digital microscope is needed that can facilitate student's multiple intelligences in plant anatomy practicum.

\section{Microscope Demand Survey}

The instrument used to survey the needs of the microscope in facilitating the learning of plant anatomy was a questionnaire instrument given to the fourth semester kaka 
who had participated in a plant anatomy practicum with 35 respondents from IAIN Shaykh Nurjati's biology education study program. The aim is to find out what kind of microscope students need in a plant anatomy practicum. The recapitulation of the response needs of a digital microscope based on blended lerning practical learning of plant anatomy can be seen in Figure 2.



\section{Figur 2. Data Analysis Summary of Student Response to the Need for Digital Microscopes based on Blended Learning}

Based on Figure 2. shows that the results of the recapitulation analysis of student response data to the initial conditions of learning anatomy plants that most students respond to agree and strongly agree with positive responses, a small portion of students respond to disagree and strongly disagree with negative responses. Then it can be seen the results of the analysis aimed at the percentage of survey results that is $79.84 \%$ with a high category.

Based on the results of the survey the need for a microscope to facilitate the plant anatomy practicum shows that students really need a digital microscope because it can make it easier to conduct cell observations, make it easy to visualize saving images easily and clearly, make it easier to identify the results of savings, make it easier to measure and count observed objects, students wanting a plant anatomy practicum can display streaming video of an object being observed using a digital microscope, and students want a plant anatomy practicum report using a web-based digital microscope / application that can be used face-to-face and online. The following is an overview of the design of a blended lerning-based digital microscope in Figure 3. 


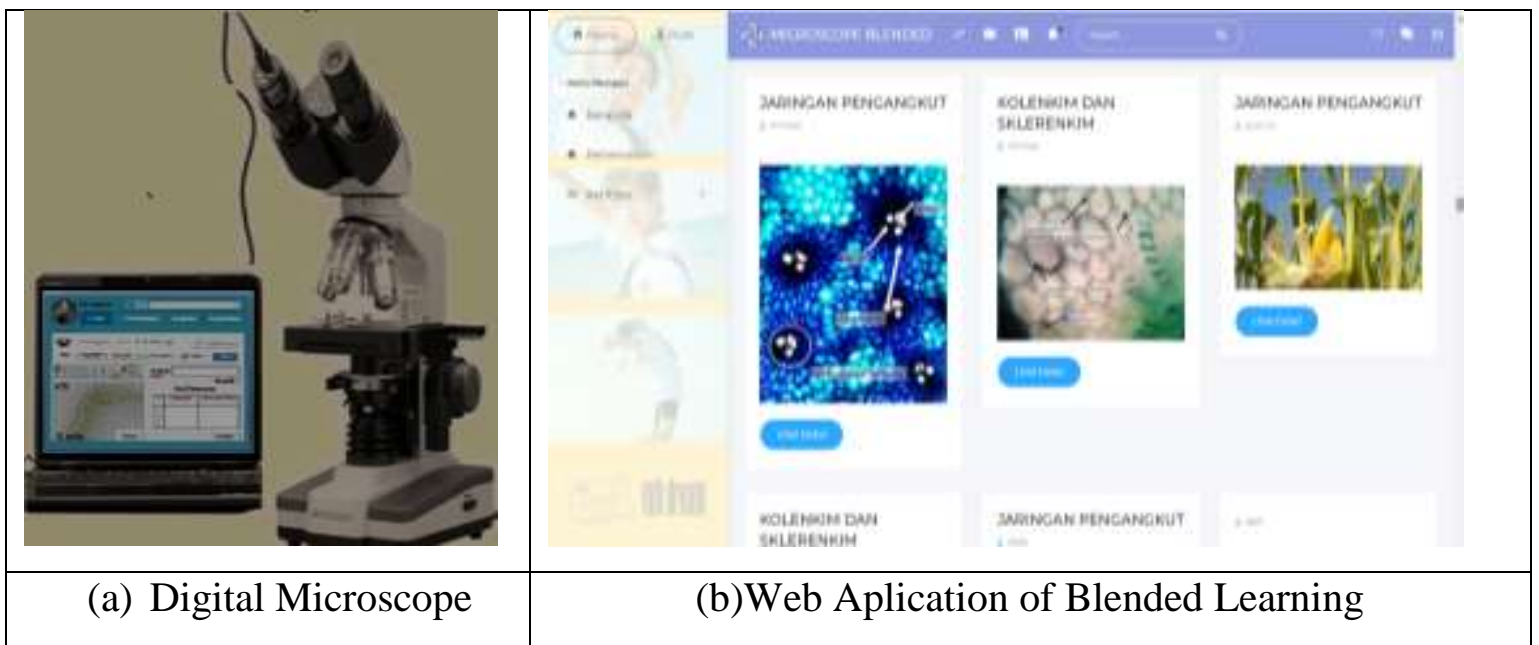

Figure 3. Digital Microscope based on Blended Learning

In response to some previous studies, the results of the questionnaire showed that the Virtual Microscope system increased student productivity and promoted learning efficiency. Furthermore, students felt other positive effects of the Virtual Microscope system in terms of additional learning resources, critical thinking, ease of communication and self-confidence (Tian et al. , 2014). Student feedback about the VM (Virtual Microscope) is very positive about the ease of use, the value of annotation tools, quizzes, and the accessibility of all components outside the campus.

Logged data analysis shows the use of VMs is quite large, although variable, by students outside the teaching schedule (Gatumu, MacMillan, Langton, Headley, \& Harris, 2014). Feedback from student users also shows virtual laboratories and remote assisted, mobile learning by improving their academic performance, after using virtual and remote laboratories (post use) as an educational platform. Feedback statistics show that $90 \%$ of students use virtual biotechnology lab techniques and it helps them to get a feel of an actual experiment.

All participants scored more than $70 \%$ in the post-test, increasing the class average of the pre-test scenario (Radhamani et al., 2015). Students are satisfied with an intelligent learning environment and blended learning learning model. In addition, the use of intelligent learning environments increases students' knowledge of programming (Kose, 2012).

Nearly all students (99\%) state that virtual slides are easy to navigate, and 93\% think that virtual image quality is better than a normal microscope (Hamilton et al., 2012). By developing an epifluorescence microscope consisting of two designs namely OPN Scope and OPN Drawer (easily accessible because of low prices), can help educators and 
students in motivating learning and conducting scientific investigations (Stewart \& Giannini, 2016).

Interactive smartphone microscopes are accessed and promote exploratory stimulation of microscopic organism observations, in a design that combines the educational, building and gaming modalities. The LudusScope touchscreen and joystick enable the selection and stimulation of phototactic microorganisms such as Euglena gracilis with light. Movement of organisms can be tracked and displayed in real time (Kim et al., 2016).

Demonstrations based on low-cost molded plastic convex lenses combined with the packaging style of our design show that portable digital microscopes can be easily implemented by displaying a high measured image resolution $>4.40 \mu \mathrm{m}$ and a measurable field of view of $5 \times 5 \mathrm{~mm} 2$. (Sumriddetchkajorn, Somboonkaew, \& Chanhorm, 2012). Students are satisfied in the conditions of blended learning using VMs, mainly because of the teacher's supporting role, the use of complementary physical microscopy and are often used throughout the duration of the practicum (Herodotou et al., 2018).

Most $(80 \%)$ students in the treatment group would prefer blended embedded learning than traditional direct lectures for future mathematics learning. Student responses to open survey questions suggest that students in the treatment group appreciate: (a) the ability to control the pace of teaching; (b) the new role of the classroom teacher; (c) lack of disruption in the mixed learning environment; and (d) accessibility of multimedia lessons embedded outside the classroom (Smith \& Suzuki, 2015).

\section{Corelation of multiple intelligence profiles on initial conditions of plant anatomy practicum to the needs of a blended learning digital microscope}

To find out the relationship between multiple intelligence profiles in the initial conditions of plant anatomy practicum and the need for a blended learning digital microscope based on the bivariate Pearson correlation test, as shown in the table below. 
Table 1. Tes of Bivariate Pearson Correlation

\begin{tabular}{llrr}
\hline & & $\begin{array}{c}\text { The initial } \\
\text { conditions of } \\
\text { multiple } \\
\text { intelligences }\end{array}$ & $\begin{array}{c}\text { The Need for } \\
\text { BBL Digital } \\
\text { Microscopes }\end{array}$ \\
\hline The initial conditions of multiple & Pearson Correlation & 1 &, $466^{*}$ \\
intelligences & Sig. (2-tailed) & 35 &, 039 \\
The Need for BBL Digital & $\mathrm{N}$ &, $466^{*}$ & 20 \\
Microscopes & Pearson Correlation &, 039 & 1 \\
& Sig. (2-tailed) & 20 & 35 \\
\hline
\end{tabular}

*. Correlation is significant at the 0.05 level (2-tailed).

Based on the significant value of the table, the value of sig is known. (2-tailed) between the initial conditions of multiple intelligences in plant anatomy practicum (X) with the needs of students for blended learning (Y) digital microscopes, is $0.039<0.05$, which means there is a significant correlation, meaning that there is a significant relationship between compound intelligence profile on initial conditions of plant anatomy practicum on the need for blended learning-based digital microscopy.

In response to some previous studies, the results of the questionnaire showed that the Virtual Microscope system increased student productivity and promoted learning efficiency. Furthermore, students felt other positive effects of the Virtual Microscope system in terms of additional learning resources, critical thinking, ease of communication and self-confidence (Tian et al. , 2014). Student feedback about the VM (Virtual Microscope) is very positive about the ease of use, the value of annotation tools, quizzes, and the accessibility of all components outside the campus.

All participants scored more than $70 \%$ in the post-test, increasing the class average of the pre-test scenario (Radhamani et al., 2015). Students are satisfied with an intelligent learning environment and blended learning learning model. In addition, the use of intelligent learning environments increases students' knowledge of programming (Kose, 2012).

\section{CONCLUSION}

Multiple intelligence profile in the initial conditions of plant anatomy practicum has low criteria, the profile of students' needs for blended learning digital microscope has high criteria, and there is a significant relationship between the profile of compound intelligence in the initial conditions of plant anatomy practicum towards the need for a blended learning digital microscope. 


\section{REFERENCES}

Barber, P. R., Tullis, I. D. C., Pierce, G. P., Newman, R. G., Prentice, J., Rowley, M. I., ... Vojnovic, B. (2013). The gray institute "open" high-content, fluorescence lifetime microscopes. Journal of Microscopy, 251(2), 154-167. https://doi.org/10.1111/jmi.12057

Gatumu, M. K., MacMillan, F. M., Langton, P. D., Headley, P. M., \& Harris, J. R. (2014). Evaluation of usage of virtual microscopy for the study of histology in the medical, dental, and veterinary undergraduate programs of a UK University. Anatomical Sciences Education, 7, 389-398. https://doi.org/10.1002/ase.1425

Hamilton, P. W., Wang, Y., \& McCullough, S. J. (2012). Virtual microscopy and digital pathology in training and education. APMIS. https://doi.org/10.1111/j.1600-0463.2011.02869.x

Herodotou, C., Muirhead, D. K., Aristeidou, M., Hole, M. J., Kelley, S., Scanlon, E., \& Duffy, M. (2018). Blended and online learning: a comparative study of virtual microscopy in Higher Education. In Interactive Learning Environments. https://doi.org/10.1080/10494820.2018.1552874

Kaufmann, A., Mickoleit, M., Weber, M., \& Huisken, J. (2012). Multilayer mounting enables longterm imaging of zebrafish development in a light sheet microscope. Development (Cambridge), 139(17), 3242-3247. https://doi.org/10.1242/dev.082586

Kim, H., Gerber, L. C., Chiu, D., Lee, S. A., Cira, N. J., Xia, S. Y., \& Riedel-Kruse, I. H. (2016). LudusScope: Accessible interactive smartphone microscopy for life-science education. PLoS ONE, 11(10), 1-16. https://doi.org/10.1371/journal.pone.0162602

Kose, U. (2012). Intelligent Learning Environments wthin Blended Learning for Ensuring Effective C Programming Course. International Journal of Artificial Intelligence \& Applications, 3(1), 105-124. https://doi.org/10.5121/ijaia.2012.3109

Krzic, U., Gunther, S., Saunders, T. E., Streichan, S. J., \& Hufnagel, L. (2012). Multiview lightsheet microscope for rapid in toto imaging. Nature Methods, 9(7), 730-733. https://doi.org/10.1038/nmeth.2064

Radhamani, R., Sasidharakurup, H., Kumar, D., Nizar, N., Achuthan, K., Nair, B., \& Diwakar, S. (2015). Role of Biotechnology simulation and remotely triggered virtual labs in complementing university education. Proceedings of 2015 International Conference on Interactive Mobile Communication Technologies and Learning, IMCL 2015. https://doi.org/10.1109/IMCTL.2015.7359548

Smith, J. G., \& Suzuki, S. (2015). Embedded blended learning within an Algebra classroom: A multimedia capture experiment. Journal of Computer Assisted Learning, 31, 133-147. https://doi.org/10.1111/jcal.12083

Stewart, C., \& Giannini, J. (2016). Inexpensive, open source epifluorescence microscopes. Journal of Chemical Education. https://doi.org/10.1021/acs.jchemed.5b00984

Sumriddetchkajorn, S., Somboonkaew, A., \& Chanhorm, S. (2012). Mobile device-based digital microscopy for education, healthcare, and agriculture. 2012 9th International Conference on Electrical Engineering/Electronics, Computer, Telecommunications and Information Technology, ECTI-CON 2012. https://doi.org/10.1109/ECTICon.2012.6254186

Tian, Y., Xiao, W., Li, C., Liu, Y., Qin, M., Wu, Y., ... Li, H. (2014). Virtual microscopy system at Chinese medical university: An assisted teaching platform for promoting active learning 
Jurnal Mangifera Edu, Volume 4, Nomor 2, Januari 2020, Halaman 84-93

and problem-solving skills. BMC Medical Education, 74(14), 1-8. https://doi.org/10.1186/1472-6920-14-74 